\title{
Analysis of the paralysis of government leadership in sub-Saharan Africa
}

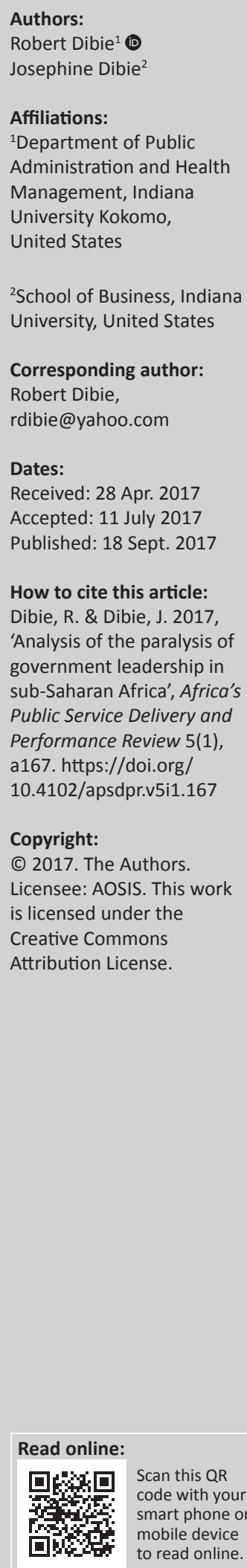

\begin{abstract}
This article examines the nature of the paralysis of public governance, leadership, conflict and economic development in selected countries in sub-Saharan Africa. It argues that ineffective political leadership and conflict will serve as a lever to poor economic growth and social development. Servant leadership and democratic representation are the continuous process of development that could be accomplished through the participation of the citizens in their own development. The dynamics of development and participation at both national and grassroots levels must involve the exposure of government change agents to peace, participatory learning and action models. The article uses data derived from primary and secondary sources to analyse the problem of political conflict, peace, leadership and economic growth. The conceptual framework is based on the structural conflict theory, negative and positive peace theories, frustration-aggression theory, physiological theories, human needs theory and economic theories. The findings show that there is a negative correlation between authoritarian political leadership and economic growth in Africa. In addition, there is a positive relationship between authoritarian political leadership and conflict in several countries in Africa. The article recommends internal and external mediation and peace education mechanisms to prevent conflict from escalating or degenerating into avoidable crises. Thus, government, private sector and nongovernmental organisations should collaborate to restore justice and equality by liberating citizens from cultural, and ethnic elements that subjugate them. The nations in sub-Saharan Africa need to establish capacity-building initiatives that could help to nurture changes in behaviour, attitudes, peace and humanist paradigm, as well as offer not only the basis for self-reliance, participatory sustainable development, but also a means to peaceful shared governance and inclusive democracy.
\end{abstract}

\section{Introduction}

A common manifestation of poor governance and the rule of law is corruption. Political corruption and no respect for rule of law or human beings are also reasons for much of the strife in Africa (Dibie, Edoho \& Dibie 2015; BBC 2016; Villalon \& Huxtable 1998). History tells us that since the Berlin Conference during the late 1800s artificial borders were drawn through territories by European colonists, throwing unfamiliar groups of Africans together and thus inciting conflicts (Bujra 2002; Falola 1998). According to Transparency International (2016) among the 10 countries considered most corrupt in the world, six are in sub-Saharan Africa. A 2002 African Union study estimated that corruption cost the continent roughly $\$ 150$ billion a year (Hanson 2009). To compare, developed countries gave $\$ 22.5$ billion in aid to sub-Saharan Africa in 2008, according to the Organization for Economic Cooperation and Development (OECD 2008; Babalola 2011). Some economists argue that African governments need to fight corruption instead of relying on foreign aid (Hanson 2009).

Several scholars have explained the reasons why African countries are finding it difficult to strive in economic development. Dibie et al. (2015) contend that the chaos of political leadership has a rhythm and flow that move multidirectionally, and through the cloud of self-aggrandisement and a discrete and elegant simplicity that defies economic development and conflict. Ake (1982 and 1996) argues that colonial legacy, social pluralism, corruption, poor planning and incompetent management, limited in-flow of foreign capital and low levels of saving and investment are the reasons for poor economic development in Africa. In addition, Ake (2005 and 1996) contends that the problem is not that development has failed, but rather that it was never really on the agenda during the de-colonialisation process. Van de Walle (2001) explains that the underdevelopment situation in Africa is because of deliberate action to prevent the continent's governments from undertaking reforms by societal interest and pressure groups, clientelism within the state elite and ideological factors. Further, Van de Walle (2001) contends that low state capacity has also 
resulted in some limited reform, but much prevarication and manipulation of the reform process, by governments that do not really believe that reform should be effective.

Change is always a challenge to African political leaders. This is because post-independence history has shown that political leaders and senior public administrators have not accepted the task confronting them in respect of transparency and accountability to the citizens. African political leaders seem to engulf with the principles of the vampire states that are characterised to have client status, personalised identity, centralised or overdeveloped morphology, a pre-bendal or rentier nature and an extractive impulse (Frimpong-Ansah 1992; Van de Walle 2003). The vampire state concept also defines the notion that they must enrich themselves at the expense of their nation's economic development. Because of this mindset of African political leaders, the traditional institutional and vertical views of work and relationship are inadequate for them to understand how to lead and implement economic changes that will benefit every citizen. According to Olanrewaju (2017) and Kalu et al. (2009), the prosperity of a nation is an indication of the kind of decisions that their political leaders make. He contends that great leaders of nations do not view their decisions from the prism of their impact on them but more about how such decisions positively affect their citizens. African political leaders who operate from this perspective will not put their own concerns and interests of their cronies above what is required by the citizens.

What is missing in the literature on African leadership is that there are assumptions that all leaders must work to harmonise the efforts of their citizens in the governance of their respective countries. It is also expected that an array of connections may together advance to economic development of their country (Adedeji 1999; Falola 2002; Reychler 2015; Yager et al. 2005 and 2014). However, these scholars fail to realise that chaos and complexity are simply the normal content for all work and relationship for leaders and administrators. Therefore, leaders must use their understanding of chaos and complexity in every element of their responsibilities to make decisions that positively affect their citizens as well as others. Dibie et al. (2015) and Olanrewaju (2017) contend that there is nothing preventing African political leaders to behave and become ethical individuals. This is because ethical credibility is the right way to etch one's legacy and name in the hearts of all citizens and not primitive accumulation of wealth.

This article examines the nature of public governance, leadership, conflict and economic development in selected countries in sub-Saharan Africa. It argues that ineffective political leadership and conflict will serve as a lever to poor economic growth and social development. Servant leadership and democratic representation are continuous processes of development that could be accomplished through the participation of the citizens in their own development. The dynamics of development and participation at both national and grassroots levels must involve the exposure of government change agents to peace, participatory learning and action models. The article uses data derived from primary and secondary sources to analyse the problem of political conflict, peace, leadership and economic growth. The conceptual framework is based on the structural conflict theory, negative and positive peace theories, frustrationaggression theory, physiological theories, human needs theory and economic theories. The findings show that there is a negative correlation between authoritarian political leadership and economic growth in Africa. In addition, there is a positive relationship between authoritarian political leadership and conflict in several countries in Africa. Thus, government, private sector and nongovernmental organisations (NGOs) should collaborate to restore justice and equality by liberating citizens from the doctrinal, cultural and ethnic elements that subjugate them. Nations in subSaharan Africa need to establish capacity-building projects that could help to nurture changes in behaviour, attitudes, peace and humanist paradigm, as well as offer not only the basis for self-reliance, participatory sustainable development, but also a means to peaceful shared governance and inclusive democracy.

\section{Leadership, conflict and peace framework}

Leadership is generally defined as the art of influencing people to work freely towards the achievement of collective goals (Griffin, Phillip \& Gully 2017). Shared governance is the core premise of good leadership (Greenberg 2013; Holzer \& Schwester 2016). Servant leadership and accountability can be especially powerful in informing the activities of public administrators and political leaders in the implementation of public policy and the delivery of goods and services to citizens in African countries. Dibie (2014) contends that if excellent leaderships are to be constructed, they should rely on lessons of liberal and representative democracy as viewed through new lenses all over the world. As a result, the essence of leadership in Africa should be getting citizens to participate in a transparent sustainable development process and economic well-being of all citizens. Citizens will be more inclined to follow leaders who exude confidence. Thus, having confidence in their abilities and conveying this confidence will ultimately make citizens feel that their leaders' decisions are correct. However, having confidence in a leader's ability may galvanize citizens to determine that following should be the right thing to do under such circumstance. In addition, new method of governance points to the changing realities in which political leaders and public administrators hold a great deal of responsibilities by working with multiple organisations. According to Agranoff and McGuire (2003) and Holzer and Schwester (2016) through partnership, networks, representation, contractual relationships, alliances, committees, coalitions, consortia and councils, political leaders and public administrators can jointly develop strategies and produce goods and services on behalf of the citizens in their country. 
Conflict is an inevitable result of interdependencies among people, work, groups and organisations (Griffin, Phillips \& Gully 2017). Conflict is a disagreement that arises when two or more parties perceive threat to their interests, needs or concerns. Conflict as used in this article refers to civil war, violent conflict, civil strife, hostility, war and political instability, interchangeably. When people, groups or organisations disagree over significant issues, conflict is often the result. In some cases, political behaviour or battle over limited resources generates conflict between groups. In addition, conflict may also result from anticipating trouble or discomfort. It might happen, when a citizen anticipates trouble in a situation in which a person may behave antagonistically towards another person whom he or she expects to pose obstacle to goal achievement (Greenberg 2013; Moorhead \& Griffin 2004). Conflict can be both constructive and destructive (Deutsch 1973; Pruitt, Rubin \& Kim 2003). Although conflict is often considered as harmful and thus something to avoid, it can have some benefits. Greenberg (2013) and Nelson and Quick (2013) contend that a total absence of conflict can lead to apathy and lethargy. On the other hand, moderate degree of conflict can stimulate new ideas, promote healthy competition and energise behaviour. It is interesting to note that several chief executive officers in non-profit organisations and NGOs consider conflict as beneficial and conducive to higher quality decision-making in all their operations (Dibie 2014; McCloud 2014).

According to Moorhead and Griffin (2004), the following theories are used to provide a framework for understanding why conflict occurs and the conditions for their resolution. The relational theory provides an explanation for a violent conflict between groups by exploring sociological, political and historical relationships among such groups (Ademola 2008; Coser 1964; Maoz 1982). The relational theory argues that in situations where multiple interest groups within a political system share a common resource that is fixed in nature, there is the tendency that each will attempt to eliminate, neutralise or injure the other or monopolise the resources, thereby entering a negative relationship (Coser 1964; Maoz 1982).

The structural conflict theory postulates that conflicts occur because of the exploitative and unjust nature of human societies (Ross 1993; Scarborough 1998). It argues that because human societies are structured in such a way that it enables one group to dominate another group conflict will often occur. Radicals like Friedrich Engel and Karl Marx blame capitalism for being an exploitative system based on its relations of production and the division of society into the proletariat and bourgeoisie (Marx 2000). According to this theory the exploitation of the proletariat and lower classes under capitalism creates conflict. The solution to this type of conflict, to the Marxists, is that the contradictions will end in a revolution or civil war or some form of violence leading to the overthrow of the exploitative system. Liberal structuralisms call leaders of nations to eliminate the structural defects with appropriate public policy of redistribution of the public goods equitably.
The frustration-aggression theory presents an argument that when expectation does not meet attainment the tendency is for people to confront those they hold responsible for frustrating their ambitions (Berkowitz 1962; Yates 1962). The theory also suggests that aggression is not just undertaken as a natural reaction or instinct, but it may be the outcome of frustration. In a situation where the legitimate needs of an individual are denied either directly or by the indirect consequence of the way the society is structured, the feeling of disappointment may lead such a person to express anger through violence that will be directed at those he or she holds responsible (Yates 1962; Moller 2006).

The economic theories argue that conflict entrepreneurs benefit from chaos while most of the population are affected by the negative impacts of conflict (Collier 2003). Collier contends that the leaders of armed formation that are perpetrating the violence often profit from the chaos. Berdal and Malone (2000) and Collier \& Binswanger (1999) observes that economic disparities, war, the crisis stage of internal conflict and so on have sometimes become a vast private and profit-making enterprise. Thus, social conflict represents at the most basic level a contest for control over economic access to wealth, resources or political systems. For example, the manufacturers of the guns used to fight wars in Africa are benefiting from the sales of weapons, while Africans are using their product to kill each other.

The human needs theory postulates that all human beings have basic needs which they seek to fulfil (Burton 1979). As a result, denial and frustration of these needs by other groups or individuals could affect them immediately or later resulting in a conflict (Rosati et al. 1990, Burton \& Dukes 1990). According to needs theory Maslow identified needs such as physiological needs, safety needs, belongingness, esteem and self-actualisation needs (Griffin et al. 2017). According to Burton (1979) such needs are human beings' response, stimulation, security, recognition, distributive justice. It also means to develop rationality, need for sense of control and need for rule defence. In addition, human beings' need for survival, protection, affection, understanding, participation, creativity and identity are shared by all people. Therefore, the absence of economic opportunities, hyperinflation and penury are manifestation of economic imbalance, while political instability leads to fear and frustration. The needs that are frustrated by institutions and norms must be pursued in one way or the other (Ademola 2008; Buton 1979; Ikejiaku \& Dauda 2011). Factors such as corruption, deprivation of basic resources and public goods and services constitute the root of bitter conflict (Porter-O'Grady \& Malloch 2015, Spencer 2012). Therefore, denial by society or government to provide materials for basic needs, recognition and identity would lead to alternative behaviour designed to satisfy such needs, be it at ethnic conflict, street gang or domestic violence (Greenberg 2013; Nelson \& Quick 2013).

There is a consensus among these theories that to resolve a conflict or to prevent one from occurring there are needs that must be met with appropriate level of equity in the 
distribution of public goods, economic resources and political power. Further, according to Ikejiaku and Dauda (2011) these theories help human beings to understand the causes, resolution and management of conflict in the African continent. The human needs theory and the physiological theories better explain why the present generation should not only blame colonialism, or neo-colonialism, global market or Africa's failure to follow Western development culture. These two theories are also different from the theories that attribute the causes of conflicts to the inherent aggressiveness of man.

Poorer countries have a considerably higher risk of civil war than rich countries; if this is supposed to apply to Africa only, then it is not necessarily true mainly because most of the African countries are very poor by most standards (Irobi 2005; Shephard et al 2013). Furthermore, civil wars are found in both poor and rich countries. Countries with abundant natural resources have a higher risk of civil wars. Some countries in Africa fall under this category; however, Botswana is doing fine with a stable democratic system. However, some countries where governments are dysfunctional may have a higher risk of civil wars (UN Development Programme 2015). This is true of the Democratic Republic of Congo, Libya, South Sudan, Sudan, Nigeria, Central African Republic and so on.

Figure 1 shows inclusiveness which means that all those who have a stake in a governance process and want to participate in it such as men and women, rich and poor, rural and urban can do so on an equal basis, whether by voting, by contributing to dialogue or by overseeing local public service agencies (Karim 2014; McCloud 2014). Inclusiveness also means that governments treat everyone equally, that they protect the rights of everyone with equal vigour, that exclusion and discrimination are absent in the provision of public services

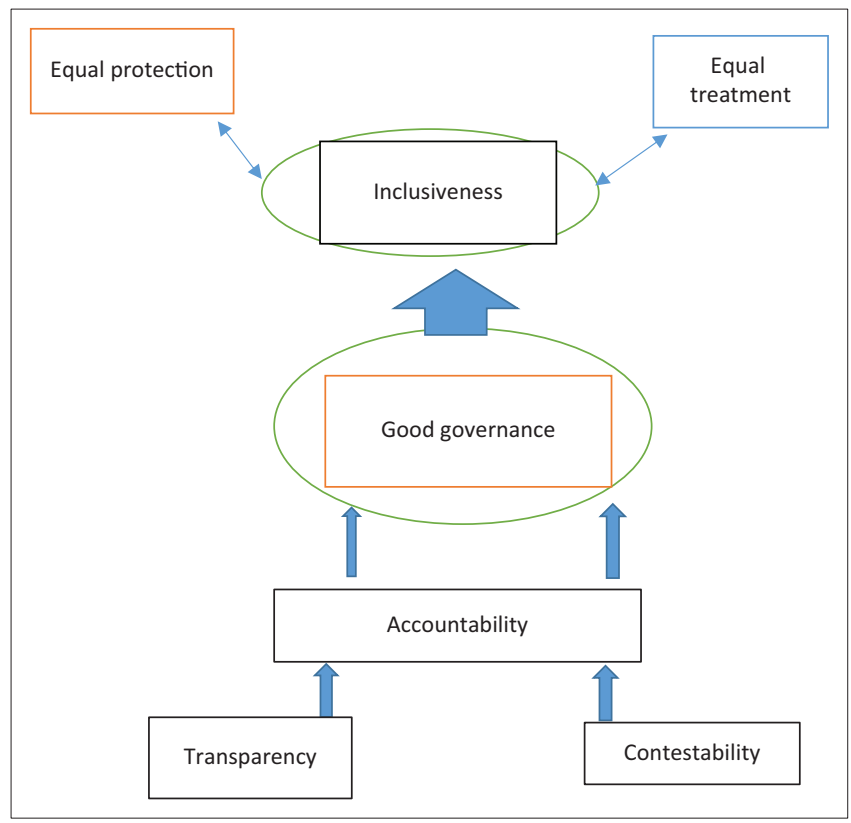

Source: World Bank 2003

FIGURE 1: Dynamics of good governance in Africa. and that everyone has equal rights to recourse and remedy if there is discrimination by public officials (World Bank 2003). Accountability is based on the idea that people have the right to hold their governments answerable for how they use the authority of the state and the resources of the people. Accountability needs transparency or full access to information. People need to know about the functioning of the government, to hold it answerable. On the other hand, governments need to provide access to such information (Ya Ni \& Wart 2016). Accountability also needs contestability, being able to choose among alternative political and economic entities based on how well they perform. It also means recourse and remedy when government actions contravene basic rights, especially those of inclusiveness, or violate the rule of law (World Bank 2003).

Social relations are basically sets of expectations that define rights and obligations, as well as status and roles. These expectations have in most cases in Africa led to disagreements or conflict (Ademola 2008; Denhardt 2004). The argument that rebel movements find it harder to organise a rebellion and to be cohesive is rather strange and goes against all the evidence in Africa. Firstly, it took only the Igbos or Hutus or Tusis to start a major civil war in Nigeria and Rwanda respectively - a highly fractionised society; the Igbos were cohesive and well organised. Secondly, the civil wars in Uganda, Sudan, Angola, DRC, Liberia, Ethiopia, Eritrea, Libya, and Rwanda are other examples of conflict in Africa (Bujra 2002 Shah 2010 and 2011). Conflicts in Sierra Leone were carried out by rebel movements, which are organised across ethnic lines. Finally, there is no need for polarisation of society (ethnically or religiously) to have a civil war, if 'political dysfunction and or development failures' are the condition prevailing in a country. According to Ademola (2008) making the type of corrections that could lead to equitable and positive relationships requires a change in leadership strategies or tactics or appropriate public policies. However, change is often resisted not because people do not see its positive values, but because they are not so keen to admit their blunders, which may be induced from within or factors that may be beyond the control of the political leader.

\section{Research method}

The objective of this article was to examine the nature of government leadership, public governance and economic development in selected countries in sub-Saharan Africa. The analysis utilised data derived through primary and secondary sources in Africa. Most of the primary data and information were derived from interviews, focus group meetings and questionnaires. The open-ended, in-depth and interactive interview approach gave the respondents the opportunity to discuss government leadership, conflict and capacitybuilding issues in Africa between 2013 and 2016. The indepth interviews were useful to capture the respondents' voice, experience and interpretation of their experiences. The sub-Saharan African continent was divided into four regions: (1) north Africa; (2) west Africa; (3) east Africa; and 
(4) south Africa. Three countries were selected from each region. Questionnaires were administered to 2500 respondents drawn from various selected countries. Those who participated in the completing the questionnaires, focus group meetings and interviews included career public servants, business executives, doctors, lawyers, law enforcement officers, teachers, housewives, traders, farmers, nurses and administrators of NGOs. A total of $1700(68 \%)$ questionnaires were completed and returned by the respondents. Data collected were analysed by using SPSS statistical tool and presented in correlations, frequency tables and percentile. The questionnaire was designed to capture data relevant to the research questions and objectives. It predominantly comprised closed ended questions to capture the nature of the political and administrative leadership in each country. Three hundred and fifty respondents from the above profile of participants attended the focus group meetings.

Interviews were conducted in the North, West, East and Southern regions. Three hundred interviews were conducted in each of the regions within three countries (100 per country). A total of 1200 one-on-one interviews were conducted. The central research questions are: (1) Do you think your political and senior administrative leaders are ethically credible? (2) Have the political leaders of your country contributed to any major economic development accomplishment? (3) Does the president of your country promote human rights, transparency and accountability towards the citizens? (4) Are the current political leaders in your country interested in shared governance and conflict resolution?

The interview, focus group meetings and survey were supplemented through an in-depth desk review and content analysis of relevant published and unpublished studies and policy and programme documents. Further, analysis of the type of political leadership problems, conflicts resolution initiatives, economic development trends and laws in selected African countries was conducted. In addition, some of the secondary data were derived through content analysis of government policy documents, annual reports produced by international agencies such as the International Labor Organization, United Nation Economic Commission for Africa, United Nations Human Development Index and the World Bank. Other data sources including staff of government agencies, ministries, departments and NGOs were interviewed to substantiate the cases in point. The findings support some the arguments presented in the literature review. The limitation of the study is that not all countries in Africa were covered by this research.

\section{Analysis of leadership, conflict and economic development}

The demography of the 1700 staff who returned their completed questionnaire showed that about $52 \%$ of them were male, while $48 \%$ were female. In addition, $40 \%$ of the respondents were from the private sector, while $50 \%$ worked in different ministries or agencies of the government. The remaining $10 \%$ of the respondents were unemployed housewives. The data also showed that most of the publicsector respondents had degrees in various disciplines. There were a few respondents working either in the private sector or in public sector who did not graduate from college. About $30 \%$ of the respondents who are traders and farmers had some qualification from tertiary institutions. Another interesting finding is that almost $40 \%$ of the respondents who work in NGOs were students' from universities or polytechnics. Half of the students were also either doing their internship or were in part-time school to complete their degree programme. Further, most of the respondents who were teachers also had private business where they sold different items and belonged to the age group between 30 and 60 years old. Table 1 shows the response to first research question.

\section{Research Question 1:}

Do you think your political and senior administrative leaders are ethically credible?

Questionnaire items 6 and 14 were utilised in the analysis of the relationship between leadership ethical credibility

TABLE 1: Nature of political leadership ethical credibility.

\begin{tabular}{|c|c|c|c|c|c|c|c|c|c|c|c|c|c|c|c|}
\hline \multirow{2}{*}{$\begin{array}{l}\text { Profile of } \\
\text { respondents }\end{array}$} & \multicolumn{3}{|c|}{ North } & \multicolumn{3}{|c|}{ South } & \multicolumn{3}{|c|}{ East } & \multicolumn{3}{|c|}{ West } & \multirow[t]{2}{*}{ Total } & \multirow[t]{2}{*}{ Yes } & \multirow[t]{2}{*}{ No } \\
\hline & $\begin{array}{c}\text { Total } \\
\text { Response }\end{array}$ & Yes & No & $\begin{array}{c}\text { Total } \\
\text { Response }\end{array}$ & Yes & No & $\begin{array}{c}\text { Total } \\
\text { Response }\end{array}$ & Yes & No & $\begin{array}{c}\text { Total } \\
\text { Response }\end{array}$ & Yes & No & & & \\
\hline Public servants & 90 & 29 & 61 & 50 & 17 & 33 & 60 & 19 & 41 & 40 & 17 & 23 & 240 & 82 & 158 \\
\hline $\begin{array}{l}\text { Business } \\
\text { executives }\end{array}$ & 50 & 16 & 34 & 36 & 15 & 21 & 42 & 19 & 23 & 42 & 18 & 24 & 170 & 68 & 102 \\
\hline Farmers & 45 & 10 & 35 & 42 & 16 & 26 & 40 & 18 & 22 & 50 & 24 & 26 & 177 & 68 & 109 \\
\hline Housewives & 40 & 14 & 26 & 35 & 17 & 18 & 40 & 10 & 30 & 55 & 24 & 31 & 170 & 65 & 105 \\
\hline $\begin{array}{l}\text { Law enforcement } \\
\text { officers }\end{array}$ & 40 & 19 & 21 & 45 & 17 & 28 & 30 & 15 & 15 & 40 & 14 & 26 & 155 & 65 & 90 \\
\hline Lawyers & 30 & 24 & 6 & 31 & 15 & 16 & 25 & 12 & 13 & 28 & 13 & 15 & 114 & 64 & 50 \\
\hline Medical doctors & 30 & 15 & 15 & 25 & 10 & 15 & 30 & 13 & 17 & 24 & 11 & 14 & 109 & 49 & 61 \\
\hline NGO staff & 30 & 14 & 16 & 45 & 20 & 25 & 60 & 25 & 35 & 50 & 25 & 25 & 185 & 84 & 101 \\
\hline Teachers & 35 & 12 & 23 & 60 & 18 & 42 & 48 & 21 & 27 & 46 & 22 & 24 & 189 & 73 & 116 \\
\hline Traders & 35 & 17 & 18 & 56 & 23 & 33 & 50 & 23 & 27 & 50 & 21 & 29 & 191 & 84 & 107 \\
\hline Total & 425 & - & - & 425 & - & - & 425 & - & - & 425 & - & - & - & 702 & 999 \\
\hline Total (\%) & - & - & - & - & - & - & - & - & - & - & - & - & - & 41.3 & 58.8 \\
\hline
\end{tabular}

Source: Derived from field research in sub-Saharan Africa 2013-2016 
and economic development. These questions highlighted data of possible reasons why political leaders and senior public administrators were considered by citizens not to be effectively involved in proactive economic development issues. Analysis of the questionnaire data showed that there was a negative relationship between political leaders' ethical credibility and economic development. Table 1 shows that $58.8 \%$ of respondents stated that their political leaders and senior administrators were not ethically credible while $41.3 \%$ indicated that some were. A weak correlation was also found in the north, south, east and western regions of subSaharan countries. It is interesting to note that $98 \%$ of the respondents indicated that electing an ethical leader is paramount to achieving good governance. The respondents believe that ethical leaders could make decisions that do not focus on how such policies would benefit their interest but the multiplying positive effective of the citizens. Therefore, ethical leaders is what sub-Saharan countries need to achieve economic development. The correlation level is shown in Table 3.

\section{Research Question 2:}

Have the political leaders of your country contributed to any major economic development accomplishment?

Table 2 shows that $64.9 \%$ of the respondents indicated that they believed their political leaders and public administrators had not done much in respect of economic development. This is because they felt that their political leaders and administrators were using government money for themselves and their family members. Respondents indicated that while the average citizen leaves with less than US\$2 a day the political leaders were busy sending their children to Europe and North America to study and vacation as well as buying expensive properties. Almost $83.5 \%$ of the farmers, housewives, teachers, traders and medical doctors interviewed indicated that the political leaders had not done much in respective of economic development. This is evident in the high rate of unemployment and dilapidated infrastructure all over their respective countries. Respondents also indicated the public schools and hospitals were poorly funded and equipped to adequately serve the needs of the low-income citizens.

Further, $57 \%$ of the public servants, business executives, lawyers and law enforcement staff who were interviewed indicated that although the government was trying to achieve positive results in some sectors in the economy, poor management and corruption were the major problems setting their respective countries back. Effective accountability, transparency and the pragmatic rule of law could help African countries to strive more for success where everyone could be better off from their current condition. On the other hand, 35\% of the respondents stated that promoting social justice in all ramification would help a lot to steer many countries towards achieving sustainable development and the idea of collective provision of common goods and services to all citizens. It is interesting to note however that all the respondents were not happy with the present practice of their respective political leaders as well as the state of their nation's poor economic development. Although several economic development initiatives were identified, the overall data showed that there was a negative relationship between political leadership ethical credibility and economic development.

Table 3 shows the weak relationship between leaders' ethical credibility (north 0.045 , south 0.046 , east 0.034 and west 0.041) and economic development (north 0.042, south 0.067 , east 0.0440 and west 0.035 ). Despite a few proactive economic development initiatives, in general the relationship between leadership ethical credibility and capacity building for sustainable development remains very weak. Thus, data from the four sub-Saharan regions and the countries selected in each sector show substantial weak relationship.

Questionnaire items 15 to 24 were utilised to evaluate political leaders' ability to promote human rights, transparency and accountability as well as shared governance and conflict resolution in the north regions. These questions highlighted data about possible proactive

TABLE 2: Nature of political leadership and economic development.

\begin{tabular}{|c|c|c|c|c|c|c|c|c|c|c|c|c|c|c|c|}
\hline \multirow{2}{*}{$\begin{array}{l}\text { Profile of } \\
\text { respondents }\end{array}$} & \multicolumn{3}{|c|}{ North } & \multicolumn{3}{|c|}{ South } & \multicolumn{3}{|c|}{ East } & \multicolumn{3}{|c|}{ West } & \multirow[t]{2}{*}{ Total } & \multirow[t]{2}{*}{ Yes } & \multirow[t]{2}{*}{ No } \\
\hline & $\begin{array}{c}\text { Total } \\
\text { Response }\end{array}$ & Yes & No & $\begin{array}{c}\text { Total } \\
\text { Response }\end{array}$ & Yes & No & $\begin{array}{c}\text { Total } \\
\text { Response }\end{array}$ & Yes & No & $\begin{array}{c}\text { Total } \\
\text { Response }\end{array}$ & Yes & No & & & \\
\hline Public servants & 62 & 23 & 39 & 45 & 22 & 23 & 53 & 20 & 33 & 39 & 9 & 30 & 199 & 74 & 125 \\
\hline $\begin{array}{l}\text { Business } \\
\text { executives }\end{array}$ & 45 & 19 & 26 & 38 & 13 & 25 & 37 & 16 & 21 & 44 & 19 & 25 & 164 & 67 & 97 \\
\hline Farmers & 53 & 21 & 42 & 57 & 21 & 36 & 63 & 21 & 42 & 56 & 24 & 25 & 229 & 87 & 145 \\
\hline Housewives & 66 & 10 & 56 & 49 & 24 & 25 & 59 & 19 & 40 & 71 & 11 & 60 & 245 & 64 & 181 \\
\hline Lawyers & 47 & 20 & 27 & 36 & 16 & 20 & 27 & 16 & 21 & 53 & 19 & 34 & 163 & 71 & 102 \\
\hline Medical doctors & 21 & 10 & 11 & 33 & 13 & 20 & 20 & 9 & 11 & 23 & 7 & 16 & 97 & 39 & 58 \\
\hline NGO staff & 10 & 2 & 8 & 60 & 20 & 40 & 51 & 11 & 40 & 30 & 11 & 19 & 151 & 44 & 107 \\
\hline Teachers & 41 & 12 & 29 & 27 & 7 & 20 & 43 & 19 & 24 & 37 & 17 & 20 & 148 & 55 & 93 \\
\hline Traders & 34 & 5 & 29 & 50 & 19 & 31 & 37 & 16 & 21 & 24 & 5 & 19 & 145 & 45 & 1000 \\
\hline Total & 425 & - & - & 425 & - & - & 425 & - & - & 425 & - & - & - & 609 & 1104 \\
\hline
\end{tabular}

Source: Derived from field research in sub-Saharan Africa 2013-2016 
perception of citizens from various sectors in the economy. Table 4 shows that $74.5 \%$ of respondents stated that the political leaders in the four regions covered in this research did not promote human rights, transparency and accountability towards their citizens. In Table 5, the result shows that $85.5 \%$ of the respondents indicated that their political leaders did not have interest in shared governance and conflict resolution. Thus, there is a weak relationship between the human rights, transparency accountability and proactive initiatives in engaging in shared governance and conflict resolution. It should be pointed out however that some countries, for example, Ghana in the west, Botswana and Republic of South Africa in the south and Tanzania in the east have demonstrated a positive relationship between transparency and accountability and shared governance. The general weak relations of the above variables are shown in Table 6.

\section{Research Question 3:}

Does the president of your country promote human rights, transparency and accountability towards the citizens?

Table 4 shows that $74.5 \%$ of the respondents stated that their government and political leaders were not promoting human rights, transparency and accountability towards the citizens nor are leaders implementing public policies that foster human rights in their respective nations. On the other hand, only $26.1 \%$ of the respondents indicated that there were some elements of human rights and accountability encouraged by their leaders. This is very important because it shows the high level of dishonesty among African leaders. Further, most African leaders are regarded by their citizens to be very authoritarian and corrupt.

TABLE 3: Correlation matrix for leadership ethical credibility and economic development.

\begin{tabular}{|c|c|c|c|c|}
\hline Factors & North index & South index & East index & West index \\
\hline Leadership ethical credibility & 0.045 & 0.046 & 0.034 & $0.410^{*}$ \\
\hline Economic development & 0.042 & 0.067 & 0.044 & 0.035 \\
\hline
\end{tabular}

Source: Derived from field research in sub-Saharan Africa 2013-2016 data analysis

*Correlation is significant at the 0.05 level (two-tailed)

TABLE 4: Promote human rights, transparency and accountability towards the citizens.

\begin{tabular}{|c|c|c|c|c|c|c|c|c|c|c|c|c|c|c|c|}
\hline \multirow{2}{*}{$\begin{array}{l}\text { Profile of } \\
\text { respondents }\end{array}$} & \multicolumn{3}{|c|}{ North } & \multicolumn{3}{|c|}{ South } & \multicolumn{3}{|c|}{ East } & \multicolumn{3}{|c|}{ West } & \multirow[t]{2}{*}{ Total } & \multirow[t]{2}{*}{ Yes } & \multirow[t]{2}{*}{ No } \\
\hline & $\begin{array}{c}\text { Total } \\
\text { Response }\end{array}$ & Yes & No & $\begin{array}{c}\text { Total } \\
\text { Response }\end{array}$ & Yes & No & $\begin{array}{c}\text { Total } \\
\text { Response }\end{array}$ & Yes & No & $\begin{array}{c}\text { Total } \\
\text { Response }\end{array}$ & Yes & No & & & \\
\hline Public servants & 29 & 11 & 18 & 60 & 19 & 41 & 50 & 17 & 33 & 37 & 10 & 27 & 176 & 57 & 119 \\
\hline $\begin{array}{l}\text { Business } \\
\text { executives }\end{array}$ & 70 & 23 & 47 & 45 & 15 & 30 & 38 & 12 & 36 & 29 & 12 & 17 & 182 & 62 & 130 \\
\hline Farmers & 55 & 10 & 45 & 53 & 18 & 35 & 56 & 17 & 39 & 59 & 9 & 50 & 223 & 54 & 169 \\
\hline Housewives & 44 & 8 & 36 & 61 & 21 & 40 & 51 & 9 & 42 & 48 & 7 & 41 & 204 & 45 & 159 \\
\hline Lawyers & 15 & 2 & 13 & 20 & 6 & 14 & 18 & 2 & 16 & 23 & 11 & 12 & 76 & 21 & 55 \\
\hline Medical doctors & 17 & 6 & 11 & 25 & 6 & 19 & 15 & 2 & 13 & 20 & 2 & 18 & 77 & 16 & 61 \\
\hline NGO staff & 72 & 13 & 59 & 44 & 13 & 31 & 55 & 9 & 46 & 58 & 6 & 52 & 229 & 41 & 188 \\
\hline Teachers & 40 & 9 & 31 & 40 & 18 & 22 & 62 & 5 & 57 & 60 & 12 & 48 & 202 & 44 & 158 \\
\hline Traders & 59 & 7 & 52 & 49 & 15 & 34 & 50 & 13 & 37 & 40 & 9 & 31 & 198 & 44 & 154 \\
\hline Total & 425 & - & - & 425 & - & - & 425 & - & - & 425 & - & - & - & 442 & 1264 \\
\hline
\end{tabular}

Source: Derived from field research in sub-Saharan Africa 2013-2016

TABLE 5: Leadership interest in shared governance and conflict resolution.

\begin{tabular}{|c|c|c|c|c|c|c|c|c|c|c|c|c|c|c|c|}
\hline \multirow{2}{*}{$\begin{array}{l}\text { Profile of } \\
\text { respondents }\end{array}$} & \multicolumn{3}{|c|}{ North } & \multicolumn{3}{|c|}{ South } & \multicolumn{3}{|c|}{ East } & \multicolumn{3}{|c|}{ West } & \multirow[t]{2}{*}{ Total } & \multirow[t]{2}{*}{ Yes } & \multirow[t]{2}{*}{ No } \\
\hline & $\begin{array}{c}\text { Total } \\
\text { Response }\end{array}$ & Yes & No & $\begin{array}{c}\text { Total } \\
\text { Response }\end{array}$ & Yes & No & $\begin{array}{c}\text { Total } \\
\text { Response }\end{array}$ & Yes & No & $\begin{array}{c}\text { Total } \\
\text { Response }\end{array}$ & Yes & No & & & \\
\hline Public servants & 52 & 13 & 39 & 38 & 12 & 26 & 49 & 11 & 38 & 64 & 11 & 53 & 203 & 47 & 156 \\
\hline $\begin{array}{l}\text { Business } \\
\text { executives }\end{array}$ & 34 & 9 & 25 & 23 & 9 & 14 & 40 & 9 & 31 & 37 & 19 & 18 & 134 & 46 & 88 \\
\hline Farmers & 56 & 6 & 50 & 63 & 6 & 57 & 58 & 3 & 55 & 55 & 6 & 49 & 232 & 21 & 211 \\
\hline Housewives & 71 & 8 & 63 & 55 & 7 & 48 & 45 & 5 & 40 & 49 & 2 & 47 & 220 & 22 & 198 \\
\hline Lawyers & 21 & 2 & 19 & 26 & 7 & 19 & 25 & 3 & 22 & 33 & 1 & 32 & 105 & 13 & 92 \\
\hline Medical doctors & 15 & 2 & 13 & 10 & 0 & 10 & 13 & 2 & 11 & 21 & 5 & 16 & 59 & 9 & 50 \\
\hline NGO staff & 42 & 0 & 42 & 64 & 13 & 51 & 49 & 6 & 43 & 45 & 3 & 42 & 200 & 22 & 178 \\
\hline Teachers & 56 & 6 & 50 & 61 & 9 & 52 & 58 & 7 & 51 & 39 & 5 & 34 & 214 & 27 & 187 \\
\hline Traders & 48 & 5 & 43 & 66 & 7 & 59 & 55 & 6 & 49 & 61 & 3 & 58 & 230 & 21 & 209 \\
\hline Total & 425 & - & - & 425 & - & - & 425 & - & - & 425 & - & - & - & 247 & 1453 \\
\hline
\end{tabular}

Source: Derived from field research in sub-Saharan Africa 2013-2016

$\mathrm{NGO}$, nongovernmental organisation. 
TABLE 6: Correlation matrix for promoting human rights, transparency and accountability, and shared governance and conflict resolution

\begin{tabular}{|c|c|c|c|c|}
\hline Factors & North index & South index & East index & West index \\
\hline $\begin{array}{l}\text { Promote human rights, transparency and accountability } \\
\text { towards the citizens }\end{array}$ & 0.044 & 0.036 & 0.043 & 0.041 \\
\hline Shared governance and conflict resolution & 0.046 & 0.046 & 0.045 & 0.037 \\
\hline
\end{tabular}

Source: Derived from field research in sub-Saharan Africa 2013-2016 data analysis

Table 7: Number of statements made by focus group question respondents.

\begin{tabular}{|c|c|c|c|c|}
\hline $\begin{array}{l}\text { Policies Issues that } \\
\text { need solutions }\end{array}$ & $\begin{array}{l}\text { Identified economic development } \\
\text { problems vote }\end{array}$ & $\begin{array}{l}\text { Vote to change current practices and } \\
\text { policies }\end{array}$ & Vote to keep current practice & Total \\
\hline \multicolumn{5}{|l|}{ Constitutional issues } \\
\hline Equal opportunity for men and women & 124 & 221 & 5 & 350 \\
\hline Equal employment for men and women & 150 & 200 & 0 & 350 \\
\hline Human rights protection for all citizens & 138 & 178 & 34 & 350 \\
\hline Civil rights for all citizens & 114 & 228 & 8 & 350 \\
\hline Political rights for all citizens & 138 & 210 & 2 & 350 \\
\hline \multicolumn{5}{|l|}{ Economic issues } \\
\hline Credit given to qualified citizens & 122 & 224 & 4 & 350 \\
\hline Ownership \& control of property & 130 & 210 & 10 & 350 \\
\hline Inheritance & 67 & 225 & 28 & 350 \\
\hline \multicolumn{5}{|l|}{ Capacity building issues } \\
\hline Education entitlements & 130 & 208 & 12 & 350 \\
\hline Health entitlements & 104 & 240 & 6 & 350 \\
\hline \multicolumn{5}{|l|}{ Labour issues } \\
\hline Abolish quota system in government jobs & 140 & 203 & 7 & 350 \\
\hline High unemployment problem & 170 & 180 & 0 & 350 \\
\hline Breaking glass ceiling for women & 175 & 175 & 0 & 350 \\
\hline Social security entitlements & 170 & 180 & 0 & 350 \\
\hline Improved working condition policies & 143 & 221 & 3 & 350 \\
\hline
\end{tabular}

Source: Derived from interviews from north, south, east, and western regions in Africa 2013-2016

While almost $79 \%$ of the interview respondents indicated that human rights, transparency and accountability were somewhat observed by their political leaders. Another $23 \%$ of the respondents stated that their leaders seemed to be above the laws. Some respondents gave a very crucial example of what they meant:

'If a poor man steals a goat he will be sentenced to jail term; however, when the minister or governor steals more than a US $\$ 100$ million, the court allows such rich leaders to refund part of it and go free'. (Some interview respondents in Nigeria).

Respondents call this double standard as oppression against the poor citizens in their respective countries. More than $80 \%$ of the respondents indicated that shared governance in their respective countries meant sharing stolen money between political leaders while the poor citizens continue to suffer. Some respondents stated that shared governance also meant 'the rich getting richer while the poor getting poorer'. The interview respondents all agreed that providing a more accountable and transparent political system where nobody is above the law could promote social justice as well as reduce conflict in the search for limited common goods.

\section{Research Question 4:}

Are the current political leaders in your country interested in shared governance and conflict?
During the four different focus group meetings, the respondents showed several discriminatory factors and characteristics that they connected to their inability to adequately contribute to the sustainable development process in their respective countries. These unlawful factors have also negatively affected their sense of empowerment and capacity building in a culture of lack of shared governance. Because of the above understanding of lack of proactive economic development and ethically credible political leadership, respondents believe that their national government needed to do more to improve the plight of its citizens. During the focus group meetings respondents voted their concerns about constitutional issues, economic predicaments, capacity-building imperatives and unemployment problems. The comments of the respondents also indicated that they were ready to venture into demanding more transparency and accountability from their respective political leaders and governments. Table 7 shows the summary of the focus group meetings.

\section{Public policy recommendations}

What can African leaders and citizens do to prevent conflict and harmful relations from escalating? An answer to this question will be the basis for the following public policy recommendation. Negotiation is an important skill in managing and resolving conflict, as well as many other economic developments, shared governance, inclusiveness and participation activities (Griffin et al. 2017). Collaborating and building consensus reflects a high concern for the 
interests of the parties in dispute. This conflict resolution public policy emphasises problem solving and pursues an outcome that gives both parties what they want (Dye 2010; Dibie et al. 2015). The collaboration approach is often regarded as the best approach to conflict resolution because it helps to fulfil both parties with a goal of 'I win and you win'.

\section{Judicial reform and restructuring of legal education}

The government judiciary system of any country must not relent in their efforts to ensure the effective administration of justice (Dibie 2014; Uwazie 2014). There is an urgent need for the restructuring of the judicial system in most African countries. It could be argued that institutional reform could also lead to the transformation of the judicial system in most African countries. The reform in the judicial system is also likely to have positive impact on critical areas such as combating corruption, commercial and investment malpractices. The bone of contention is however the fair and impartial administration of justice where nobody is above the law or constitutional provisions of any African country. The judicial system also needs to keep abreast with the growing best practice in the field. Vigorous involvement of legal practitioners through the judicial system in conflict resolution should be regarded as part of the sustainable development process. This is necessary to curtail apathy towards conflict resolution among legal practitioners. The restructuring of the legal education to cover a full study course in alternative dispute resolutions should also be part of the judicial reform process. It is anticipated that in future alternative dispute resolution experts will help to respond to the conflict challenges in Africa.

\section{Solution for corruption}

To escape the vicious cycle that corruption has created for disadvantaged groups, people need to be able to speak up for their rights and demand accountability from their leaders, ensuring access to basic social services and resources. If the social contract between the government and the people fails, citizens and the poor people are forced to compromise on the quality of their livelihoods and their social and human rights (Allen 2013; Dibie et al. 2015). Further, programmes that could enable disadvantaged people to take part in the development processes by opening dialogue between them and their governments should be established. If people have a say in how they are governed (participatory governance) and officials are accountable to the people they serve (social accountability), poor people become aware of their power and the force their voices have when raised. Therefore, servant leadership values, integrity principles and empowered citizens could benefit from being considered champions of economic growth, and the national development (Transparency International, 2016).

Experts suggest a variety of methods for African governments to battle corruption, with a special emphasis on transparency and accountability. These methods include: (1) creating anti-corruption agencies, (2) strengthening existing institutions, (3) reducing dependency on foreign aid and (4) the role of global partners. Some analysts argue that one of the most effective ways to reduce corruption is targeting transactions related to natural resources extraction, a major source of revenue in many African countries from the Democratic Republic of Congo to Angola and Nigeria (Dibie 2014; Hanson 2009).

\section{Economic development and capacity building}

Economic growth is important because it keeps all nations moving in a positive, productive direction (Dibie et al 2015; Mandel 2013; Mankiw 2018). Increased economic growth in Africa may enhance or increase employment opportunities. The neoclassical approach to economic growth prescribes two basic premises (Froeb et al. 2016). A free market economy is important in the economic development of a country. Clear and serious uneven distribution of economic resources between regions and ethnic groups is known to have led to conflict, sometimes to serious secessionist rebellion. An enabling environment free of conflict is where economic growth can take place (Froeb et al. 2016). Helping citizens to meet their needs such as job creation and full employment will also reduce conflict. In addition, good governance and minimal government intervention in the private production of goods and services, minimal management of industry strategies and a more regulatory approach to social and individual responsibilities could rejuvenate sustainable development in Africa (Beegle et al. 2016; Ya Ni \& Wart 2016).

\section{Enhancing good governance and nation building}

Good governance is also about accountabilities, which depend on information, transparency and recourse contestability. Because the difficulty in ensuring inclusiveness and accountability in the governance process is so complex, many approaches have evolved to expand and defend inclusiveness and to hold governments, and government officials, more accountable.

For policymakers trying to improve their economy's regulatory environment for business, a good place to start is to find out how it compares with the regulatory environment in other economies. Nation capacity building is essentially a long-term process and it needs long-term strategies and policies whose impact will prevent the emergence of conditions that give rise to stagnated economic growth (Miller 2016; Nwazor 2012).

Table 8 shows the current lack of term limit in many countries in sub-Saharan Africa. While the President Mugabe of Zimbabwe has been in power for 37 years, President Yoseveni of Uganda has also been in office for 31 years. The president of Gabon 49 years and his colleague in Angola continues to be the president of his country after 38 years in the same position. On the other hand, President Paul Biya of Cameroon has also been in office for 35 years, President Omar Bashir of Sudan 28 years and President 
TABLE 8: Nature of political leadership in selected African countries.

\begin{tabular}{|c|c|c|c|c|c|}
\hline Name of country & Name of leader & Duration in office & Years & Style of leadership & Population of country \\
\hline Angola & Jose Edwardo dos Santos & 1979-2017 & 38 & Brutal dictator and unitary presidential republic & 24.3 million \\
\hline Benin & Thomas Boni & $2006-2017$ & 35 & Brutal dictator & 9.4 million \\
\hline Cameroon & Paul Biya & $1982-2017$ & 35 & Dominant party presidential republic & 20 million \\
\hline Egypt & Itsni Mubarak & $1981-2011$ & 30 & Authoritarian regime & 90.7 million \\
\hline Equatorial Guinea & Obiang Nguema & 1979-2017 & 38 & Brutal dictator and control of the media & 740000 \\
\hline Chad & Idriss Deby & $1990-2017$ & 27 & Authoritarian regime & 11.8 million \\
\hline Democratic Republic of Congo & Mobuto Sese Seko & 1965-1997 & 32 & Brutal dictator and control of the media and central bank & \\
\hline \multirow[t]{2}{*}{ Gabon } & Omar Bango & 1960-2009 & 49 & Brutal dictator & 1.5 million \\
\hline & Ali Bango & 2009-2017 & 8 & Semi-democratic & \\
\hline Gambia & Yahya Jammeh & 1994-2017 & 23 & Authoritarian regime & 1.8 million \\
\hline Libya & Maummar Gaddafi & 1969-2011 & 42 & Brutal dictator & 6.4 million \\
\hline \multirow[t]{2}{*}{ Sao Tome } & Pinto da Costa & 1975-1990 & 15 & Semi-democratic & 172000 \\
\hline & & 2011-2017 & 6 & & \\
\hline Uganda & Yoweri Yoseveni & $1986-2017$ & 31 & Semi-democratic & 35.6 million \\
\hline Zimbabwe & Robert Mugabe & 1980-2017 & 37 & Brutal dictator & 13 million \\
\hline
\end{tabular}

Source: Central Intelligence Agency 2008-01-03

Thomas Boni of the Republic of Benin 35 years. The new trend in the sub-continent is that current presidents such as those of Kenya, Uganda, Rwanda, Zimbabwe, Cameroon and so on have systematically manipulated their national assembly to change the constitution for them to seek extended term in office as president. The lack of term limit has created a lot of economic development, social and political problems in Africa. These vampire presidents that want to perpetually stay in office are so corrupt and authoritarian in all ramifications.

To establish the right environment for industrial development as well as appropriate business and government relations, there is a need to develop a political system whose laws allow competition for power and which guarantee the possibility of alternate groups achieving power within a reasonable period. Term limits of 4 or 5 years should be required by the provisions of the constitution, and no sitting president should be allowed to amend the constitution for his or her benefit (Bamfo 2009; Dibie 2014).

The democratic political system should allow large numbers and groups to be involved in the selection or election of decision-makers at different levels of the power structure. Several important principles are absolutely critical to such a political system: (1) extensive decentralisation of power; (2) accumulation of wealth through the use of state institutions must be totally forbidden; (3) the principles of good and democratic governance must be fully implemented, i.e. transparency, accountability, independent judiciary and local action; (4) extensive involvement of indigenous, independent civil society groups in national and local affairs especially in the monitoring of policy implementation and service delivery (Dibie 2014; Froeb 2016; OECD 2007). Figure 2 shows a model on how to enhance governance. If political and public administration leaders are serious about transformation of their governance performance and system they should adopt the model in Figure 2.
Figure 2 shows a pathway programme to enhance governance. This pathway could be elaborated along five principles of good governance: (1) national actions to strengthen external accountability, (2) national checks and balances to strengthen internal accountability, (3) measures to enhance inclusiveness, (4) administrative reform to improve internal accountability,

(5) local actions to strengthen external accountability and (6) adoption of laws and regulations (Ake 2005; Dibie 2003; Katzioloudes 2006; OECD 2007).

\section{Conclusion}

This article has examined government leadership, conflict and economic development in sub-Saharan Africa. It argues that ineffective political leadership and conflict will serve as a lever to poor economic growth and social development in the continent of Africa. The article identified the following as the major causes of conflict in Africa: personalisation of both the national government and regime, the Vampire State, poverty and slow economic development, ethnicity and competition for control political power, religion and lack of term limit problems. Although internal and external mediations are suggested to resolve conflict in Africa, a calculated and responsive mediator can be used to leverage incentives to minimise insecurity and prevent intense conflict from occurring or escalating out of control.

The article also explored strategic imperative approaches such as inclusiveness, responsiveness and efficiency in governance, servant leadership, trust creation and confidence building as mechanism for development. In addition, it examined decentralisation of power to the grassroots, pluralism and decentralisation of the economy, political communication, education, promotion and defence of human rights as possible solutions. Other factors include creation of an effective judicial system where no one including the president is above the law, creation of appropriate political machinery and popular participation in all aspects of the development process. 


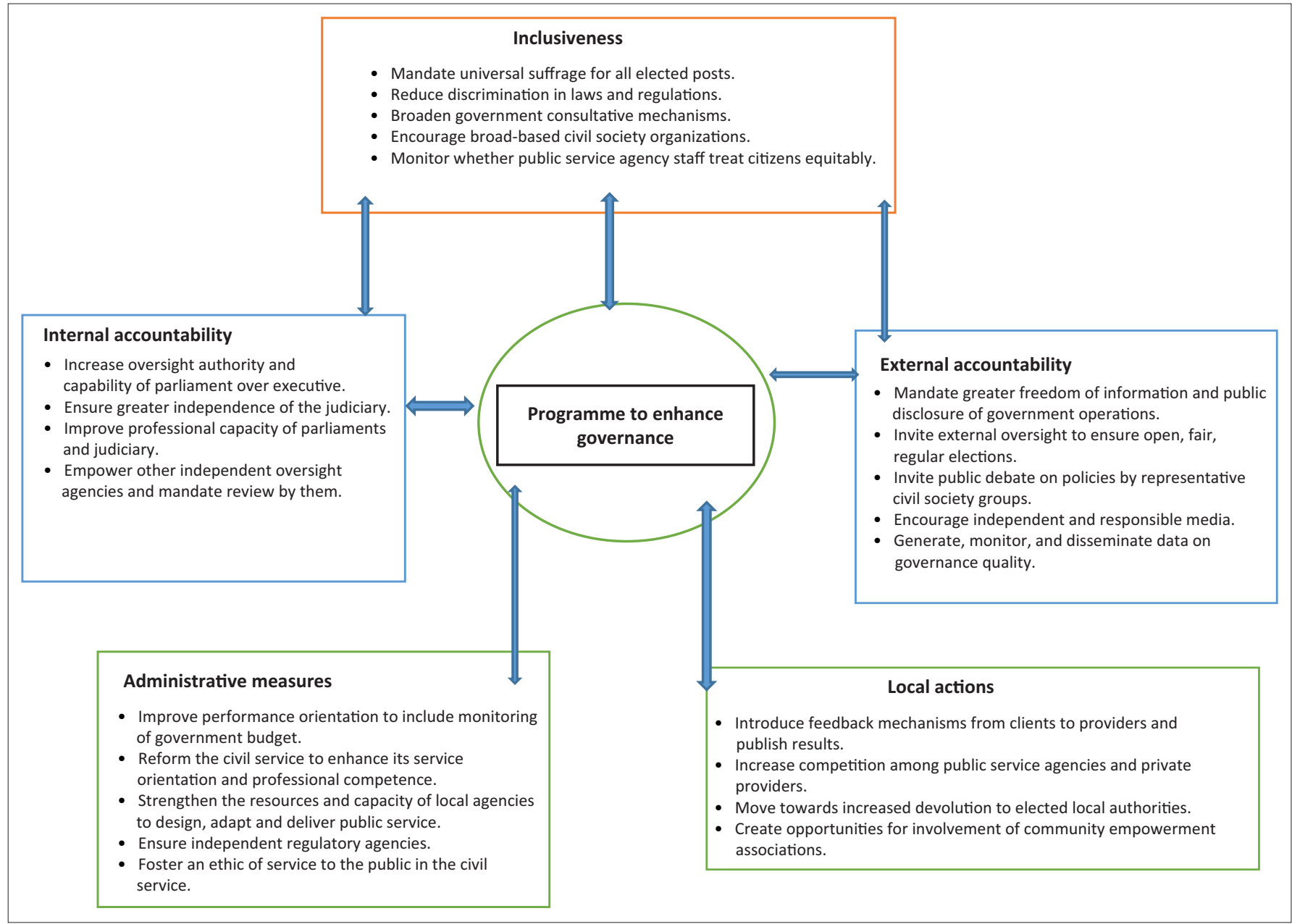

Source: Organization for Economic Cooperation and Development (OECD), 2007, Business for development: Fostering the private sector, viewed 04 April 2016, from http://www.oecd.org/dev FIGURE 2: Enhance governance model.

Other scholars also contend that good governance in Africa should include: (1) national actions to strengthen external accountability, (2) national checks and balances to strengthen internal accountability, (3) measures to enhance inclusiveness, (4) administrative reform to improve internal accountability, (5) local actions to strengthen external accountability and (6) adoption of laws and regulations (Dibie 2003; Katzioloudes 2006; OECD 2007; Uwazie 2014).

Finally, governance network will provide the opportunities for citizen participation. Cooperative network will enhance more effective regulatory control and the expression of public sector values within the marketplace in Africa. This will happen because of the sense of shared responsibility and the dependent relationship (Aforlabi 2003; Kraft \& Furlong 2016; Nwoke 2010). Judicial reform and a free media are also an important instrument to encourage participation of civil society groups and citizens in conflict resolution in Africa. Participatory social accountability tools will increase contact between citizens and governments and therefore increase transparency, accountability and good governance. Therefore, the positive attributes of inclusive governance encompass material well-being, wider choices and opportunities for people to realise their potentials and the guarantee of equity of treatment, freedom to choose and full participation in the process by which citizens govern themselves in all countries in Africa. One fact is that it will take Africans to develop their respective countries. Africans must be the change they wish to see in the continent and they must develop a common sense approach to economic development goals.

\section{Competing interest}

The authors declare that they have no financial or personal relationships which may have inappropriately influenced them in writing this article.

\section{Authors' contributions}

R.D. was the project leader and J.D. wrote part of the introduction and administered some of the questionnaires in west Africa. R.D. and J.D. collaborated in using SPSS to perform the analysis of the data. R.D. conducted the focus group meetings and wrote the literature review and the policy recommendations. J.D. and R.D. designed the research methods and wrote the analysis and conclusion sessions of the article. 


\section{References}

Adedeji, A., 1999, Comprehending and mastering African conflicts, Zed Books, London.

Ademola, F.S., 2008, 'Theories of social conflict', in S.G. Best (ed.), Introduction to peace and conflict studies in West Africa, Spectrum Books Limited, Ibadan, Nigeria, pp. 21-27

Aforlabi, A.A., 2003, 'Electoral violence and the democratization project: The Nigerian experience', in B.A. Olausson (ed.), Electoral violence in Nigeria: Issues and perspective, Friedrich Ebert Stiftung Press, Manila, pp. 79-91.

Agranoff, R. \& McGuire, M., 2003, Collaborative public management, Georgetown University Press, Washington, DC.

Ake, C., 1982, Political economy of Africa, Longman Press, London.

Ake, C., 1996, Democracy and development in Africa, Brookings Institution Press, Washington, DC.

Ake, C., 2005, The feasibility of democracy in Africa, Codesria Press, Darker, Senegal.

Allen, J., 2013, Africa: Governments failing in corruption fight, viewed 14 April 2016, from http://allafrica.com/stories/201311131025.html

Babalola, J., 2011, '520 died in Kaduna, Niger Delta violence, says Ringim', The Nation, 2 June, pp. 1-2.

Bamfo, N., 2009, 'Term limit and political incumbency in Africa: Implications of staying in power too long with references to the cases of Kenya, Malawi, and Zambia African and Asian Studies 4(3), 327-356. https://doi.org/10.1163/15692090577 4270439

BBC News, 2016, South Africa country profile, viewed 18 April 2016, from http://www. bbc.com/news/world-africa-14094760

Beegle, K. Dabalen, C.L. \& Gaddis, I., 2016, Poverty in a rising Africa, World Bank Washington, DC, (c) World Bank, viewed May 25, 2016 from https:// openknowledge.worldbank.org/handle/10986/22575License:CCBY3.0IGO

Berdal, M. \& Malone, D. M. 2000, eds. Greed and grievance: economic agendas in civil wars, Lynne Rienner, Boulder, CO.

Berkowitz, L. 1962, Aggression: A sociological analysis, McGraw-Hill, New York.

Best, S.G., 2008, Introduction to peace and conflict studies in West Africa, Spectrum Books Limited, Ibadan, Nigeria.

Bujra, A., 2002, African conflicts: Their causes and their political and socia environment, Development Policy Management Forum (DPMF), Addis Ababa, Ethiopia.

British Broadcasting Corporation (BBC), 2004, How deep is corruption in Africa? viewed 14 April 2016, from http://news.bbc.co.uk/2/hi/africa/3819027.stm

Burton, J., 1979, Deviance, terrorism and war: The process of solving unsolved social and political problems, Macmillan, London.

Burton, J. \& Dukes, F., eds., 1990, Conflict: Readings in management and resolution Macmillan, London and St. Martins Press, New York.

Central Intelligence Agency, 2008-01-03, Where in the World is Mt. Kilimanjaro? Visit the CIA World Factbook to Find Out, viewed 15 April 2016, from https://books. google.com/books?id=tO5VAQAACAAJ\&dq=Central+Intelligence+Agency, +2008 \&hl=en\&sa=X\&ved=0ahUKEwj92LGm8dXVAhUCeCYKHaWtAesQ6AEILTAB

Collier, P., 2003, Breaking the conflict trap: civil war and development policy, The World Bank, Washington DC.

Collier, P. \& Binswanger, H., 1999, Ethnic loyalties, state formation and conflict, a background paper prepared for the Africa in the 21st Century Project, World background paper prepar
Bank, Washington, DC.

Coser, P., 1964, The function of social conflict, Free Press, New York.

Denhardt, R., 2016, Theories of Publix Organizations, Cengage Learning, Belmont, CA.

Deutsch, M., 1973, 'Conflicts: Productive and destructive', in F.E. Jandt (ed.), Conflict resolution through communication, Harper \& Row, New York, pp. 30-42.

Dibie, R., 2003, 'Managing political and ethnic diversity in sub-Saharan Africa', in E. Uwazie (ed.), Conflict resolution and peace education in Africa, Lexington Books, Laham, MD, pp. 161-176.

Dibie, R., 2014, 'Civil society and conflict resolution in the Niger Delta of Nigeria', in E. Uwazie (ed.), Alternative dispute resolution and peace-building in Africa, Cambridge Scholars Publishing, Newcastle upon Tyne, England, pp. 121-150.

Dibie, R., Edoho, F.M. \& Dibie, J., 2015, 'Analysis of capacity building building and economic growth in sub-Saharan Africa.' International Journal of Business and Social Sciences 6(12), 1-25.

Dye, T., 2010, Understanding public policy, Congressional Quarterly Press, Washington, DC.

Falola, T., 1998, Violence in Nigeria: The crisis of religious politics and secular ideologies, University of Rochester Press, Rochester, NY.

Falola, T., 2002, The end of colonial rule: Nationalism and de-colonialization, Carolina Academic Press, Durham, NC.

Frimpong-Ansah, J.H., 1992, The Vampire State in Africa: The political economy of decline in Ghana, African World Press, Trenton, NJ.

Froeb, L.M., McCann, B., Shor, M. \& Ward, M., 2016, Managerial economics: A problem-solving approach, 4th edn,. Learning, Boston, MA.

Greenberg, J., 2013, Managing behaviour in organizations, 6th edn., Pearson, Boston, MA.
Griffin, R., Phillips, J.M. \& Gully, S.M., 2017, Organizational behavior: Managing people and organizations, Cengage Learning, Boston, MA.

Hanson, S., 2009, Corruption in Africa, viewed 14 April 2016, from http://www.cfr.org/ africa-sub-saharan/corruption-sub-saharan-africa/p19984

Holzer, M. \& Schwester, R., 2016, Public administration, Routledge Press, New York.

Ikejiaku, B. \& Dauda, J., 2011, 'African Union, conflict, and conflict resolution in Africa: A comparative analysis of recent Kenya and Zimbabwe conflicts', International Journal of Development and Conflict 1(1), 61-90. https://doi.org/10.1142/ S2010269011000105

International Monetary Fund, 2006, World economic outlook: Financial system and economic cycles, International Monetary Fund Publication, Washington, DC.

Irobi, E., 2005, Ethnic conflict management in Africa: A comparative case consortium, University of Colorado, Denver, CO.

Kalu, K., 2004, Agenda setting and public policy in Africa, Ashgate Press, Burlington,

Kalu, K. \& Soyinka-Arewele, P., 2009, Socio-political scaffolding and the constitution of change, African World Press, Trenton, NJ.

Karim, A.A., 2014, 'Electoral disputes in Africa: Causal analysis and proposal for alternative dispute resolution mechanism for resolution', in E. Uwazie (ed.), Alternative dispute resolution and peace-building in Africa, Cambridge Scholars Publishing, Newcastle upon Tyne, England, pp. 37-52.

Katsioloudes, M., 2006, Strategic management: Global cultural perspectives for profit and non-profit organizations, Elsevier Butterworth-Heinemann, Burlington, MA.

Kraft, M. \& Furlong, S., 2016, Public policy analysis, Congressional Quarterly Press, Washington, DC.

Lerenz, K., 1966, On aggression, Harcourt Brace World Press, New York.

Mandel, M., 2013, Economics: The basics, Mcgraw Hill Irwin, New York.

Mankiw, N.G., 2018, Macroeconomics, 8th edn., Cengage Learning, Boston, MA.

Maoz, Z., 1982, Paths to conflict international dispute initiation. 1816-1997, Westview Press, Boulder, $\mathrm{CO}$

Marx, K. (2000). Karl Marx: Selected writings, 2nd edn., David McLellan (ed.), Oxford University Press, Oxford.

McCloud, L.J., 2014, What are the causes of political conflict in Africa?, viewed 12 April 2016, from http://www.ehow.com/list_7370582_causes-political-conflict-africa_.
html

Miller, R.L., 2016, Economics today, 18th edn. Pearson Learning, Boston, MA.

Møller, B., 2006, Religion and conflict in Africa: With a special focus on East Africa, Danish Institute for International Studies, Copenhagen, Denmark.

Moore, A., 2014, Five devastating religious conflicts in Africa that will make you question all you thought about religion, viewed 18 April 2016, from http:// atlantablackstar.com/2014/05/31/5-devastating-religious-conflicts-in-africa-thatwill-make-you-question-all-you-thought-about-religion $\% \mathrm{e} 2 \% 80 \% 8 \mathrm{f} /$

Moorhead, G. \& Griffin, R., 2004, Organizational behavior, Houghton Mifflin Company, New York.

Nelson, D. \& Quick, J.C., 2013, Organizational behaviour, South-Western Cengage Learning, Mason, $\mathrm{OH}$.

Nwazor, J.C., 2012, 'Capacity building entrepreneurship and sustainable development', Journal of Emerging Trends in Education Research and Policy Studies 3(1), 51-54.

Nwoke, C.N., 2010, 'Election violence, democratic misadventure underdevelopment', paper presented at Roundtable on Democracy and the 2011 Election in Nigeria. Conference Organized by the African Center for Peace Research, Empowerment and Documentation (ACPRED), llorin, 21-23 September.

Olanrewaju, S., 2017, 'Leaders, ethics and decision making', Nigerian Tribune Newspaper, Ibadan, Nigeria, 13 February, pp. 1-2.

Organization for Economic Cooperation and Development (OECD), 2007, Business for development: Fostering the private sector, viewed 04 April 2016, from http:// www.oecd.org/dev

Organization for Economic Cooperation and Development (OECD), 2008, Business for development: Fostering the private sector, viewed 04 April 2016, from http:// www.oecd.org/dev

Porter-O'Grady, T. \& Malloch, K., 2015, Leadership: Building better partnership for sustainable health, Jones \& Bartlett Learning, Burlington, MA, pp. 22-26.

Pruitt, D., Rubin, J. \& Kim, S. 2003, Social conflict: Escalation, stalemate, and settlement, 3rd edn., McGraw-Hill, New York.

Reychler, L., 2015, 'Religion and Conflict', The International Journal of Peace Studies, viewed 21 April 2017 from http://www.gmu.edu/programs/icar/ijps/vol2_1/ Reyschler.htm

Rosati, J., Carroll, D. \& Coate, R. 1990, 'A critical assessment of the power of human needs in world society', in J. Burton, Conflict human needs theory, Macmillan London and St. Martin's Press, New York, pp. 1-14.

Ross, M., 1993, The management of conflict: Interpretations and interests in comparative perspective, Yale University Press, New Haven, CT.

Rubenstein, R., 2001, 'Basic human needs: The next steps in theory development', The International Journal of Peace Studies 6(1), 13-27.

Scarborough, G.I., 1998, 'An expert system for assessing vulnerability to instability,' in J. David \& T.R. Gurr, eds., Preventive measures: Building risk assessment and crisis early warning systems, Rowan and Littlefield, Lanham, pp. 142-158. 
Shah, A., 2010a, Conflict in Africa, viewed 13 April 2016, from http://www. globalissues.org/article/84/conflicts-in-africa-introduction

Shah, A., 2010b, The Democratic Republic of Congo, viewed 17 April 2016, from http://www.globalissues.org/article/87/the-democratic-republic-of-congo

Shah, A., 2011, Libya and the unrest throughout the Middle East and North Africa, viewed 16 April 2016, from http://www.globalissues.org/article/793/libya

Shepherd, A., Mitchell, T., Lewis, K., Lenhardt, A., Jones, L., Scott, L. et al., 2013, The geography of poverty, disasters and climate extremes in 2030, viewed 12 April 2016, from http://www.odi.org/publications/7491-geography-poverty-disastersclimate-change-2030

Spencer, R., 2012, 'Violence breaks out across Egypt as protesters decry Mohammed Morsi's constitutional "coup"', The Daily Telegraph, viewed 16 April 2016, from http://www.telegraph.co.uk/news/worldnews/africaandindianocean/ egypt/10163487/Egypt-crisis-at-least-29-killed-as-Muslim-Brotherhood-clashwith-ousted-Mohammed-Morsis-enemies.html

Transparency International, 2016, Poverty and corruption in Africa, viewed 14 April 2016, from http://www.transparency.org/whatwedo/activity/poverty and corruption_in_africa

United Nations Development Programme, 2015, Human development report, Oxford University Press, New York.

Uwazie, E., 2014, Alternative dispute resolution and peace-building in Africa, Cambridge Scholars Publishing, Newcastle upon Tyne, England.

Van de Walle, N, 2001, African economies and the politics of permanent crisis, 1979-1999, Cambridge University Press, New York.
Van de Walle, N., 2003, 'Presidentialism and clientelism in Africa's emerging party system', Journal of Modern African Studies 9, 297-310. https://doi.org/10.1017/ S0022278X03004269

Villalon, L.A. \& Huxtable, P.A., 1998, The African state at a junction: Between disintegration and reconfiguration, Lynne Rienner Publishers, Boulder, $\mathrm{CO}$.

World Bank, 2003, Better governance for development in the Middle East and North Africa: Enhancing inclusiveness and accountability, World Bank Press, Washington, DC

World Bank, 2016, Poverty in a RISING Africa: Poverty report, viewed 14 April 2016, from https://openknowledge.worldbank.org/bitstream/handle/10986/22575/32962 PovertyInARisingAfrica_overview.pdf?sequence=13\&isAllowed $=y$

Yager, T.R., Bermúdez-Lugo, O., Mobbs, P.M., Newman, H.R., Taib, M., Wallace, G.J. et al., 2014, The mineral industries of Africa. USGS 2012 Minerals Yearbook, Africa Summary, December 2012. World Development Report. Oxford University Press, New York.

Yager, T.R., Bermudez-Lugo, O., Mobbs, P.M., Newman, H.R. \& Wilburn, D.R., 2005 The mineral industries of Africa. United States Geological Survey Minera Year Book, PD License, United States Government Service Public Domain, viewed 28 May 2017 from https://minerals.usgs.gov/minerals/pubs/country/2004/ africa04.pdf

Ya Ni, A. \& Wart, M.V., 2016, Building business-government relations: A skills approach Routledge Press, New York.

Yates, A., 1962, Frustration and conflict, Methuen Publishers, London. 